\title{
FRESHWATER AVAILABILITY AND CONSTRAINTS ON THERMOELECTRIC POWER GENERATION IN THE SOUTHEAST U.S.
}

Final Report to the U.S. Department of Energy for Cooperative Agreement number DE-FC21-03NT41717

Period Covered: June 1, 2003 to June 30, 2008

The Southern States Energy Board 6325 Amherst Court

Norcross, GA 30092

Phone: 770-242-7712; Fax: 770-242-9956

www.sseb.org

with information supported by a subgrant with

The University of Tennessee, Knoxville

June 2008

Principal Investigators: David L. Feldman, Ph.D.,

Amanda Slough, Candidate, Master of Science in Planning

Department of Political Science

The University of Tennessee, Knoxville

Gary Garrett

Senior Technical Analyst

Southern States Energy Board 


\section{NOTICE}

This report was prepared as an account of work sponsored by an agency of the United States Government. The United States Government, nor any agency thereof, nor any of their employees, makes any warranty, express or implied, or assumes any legal liability of responsibility for the accuracy, completeness, or usefulness of any information, apparatus, product, or process disclosed, or that its use would not infringe privately owned rights. Reference herein to any specific commercial product, process, or service by trade name, trademark, manufacturer, or otherwise, does not necessarily constitute or imply its endorsement, recommendation or favoring by the United States Government, or any agency thereof. The views and opinions of authors expressed herein do not necessarily state or reflect those of the Southern States Energy Board, or the United States Government, or any agency thereof.

This Final Report was prepared with the support of the U.S. Department of Energy, under award DE- FC21-03NT41717. However, any opinions, findings, conclusions, or recommendations expressed herein are those of the author (s) and do not necessarily reflect the views of the DOE. 


\section{Freshwater Availability and Constraints on Thermoelectric Power Generation in the Southeast U.S.}

\begin{tabular}{lc} 
& Table of Contents \\
Abstract & Page \\
Introduction & 4 \\
Baseline Water Usage & 6 \\
Constraints & 9 \\
Hydrologic & 10 \\
Groundwater depletion & 10 \\
Water Quality degradation & 10 \\
Surface Water Challenges & 11 \\
Desalination & 13 \\
Societal & 15 \\
Economic & 16 \\
Nuclear Power & 17 \\
Clean Coal Technologies & 18 \\
Coal to Liquids & 20 \\
Ethanol & 20 \\
Impacts of Wind Generation & 21 \\
Total Maximum Daily Load & 22 \\
Policy & 23 \\
Permits & 23 \\
NPDES & 26 \\
Clean Water Act 316(b) & 26 \\
Permit Compliance System & 26 \\
Climate Change Effects & 27 \\
Carbon Capture and Storage & 27 \\
Conclusions & 30 \\
Glossary & 31 \\
Bibliography & 33 \\
& 38 \\
\hline
\end{tabular}




\title{
FRESHWATER AVAILABILITY AND CONSTRAINTS ON THERMOELECTRIC POWER GENERATION IN THE SOUTHEAST U.S.
}

\author{
David L. Feldman, Ph.D., Project Director, \\ Professor and Head of the Department of Political Science, \\ Amanda Slough, Principal Author, Candidate, Master of Science in Planning \\ Gary Garrett, Senior Technical Analyst, Southern States Energy Board
}

\begin{abstract}
There is a myriad of uses to which our country's freshwater supply is currently committed. Together with increasing quantities of consumption, there are growing constraints on water availability. In our future there will be two elements of consumption at the forefront of concern: availability and efficiency. Availability of freshwater is the most important of these and is the subject of this report. To use water efficiently, we must first have it. Efficiency is key to ensuring availability for future needs. As population grows and economic and technology demands increase - especially for thermoelectric power - needs for freshwater will also increase. Thus, using our limited supplies of freshwater must be done as efficiently as possible.
\end{abstract}

Thermoelectric generating industry is the largest user of our nation's water resources, including fresh, surface, ground, and saline water. Saline water use accounts for approximately 30\% of thermoelectric use, while the remaining $70 \%$ is from freshwater sources. The U.S. Geological Survey (USGS) estimates that thermoelectric generation accounts for roughly 136,000 million gallons per day (MGD), or 39\% of freshwater withdrawals. This ranks slightly behind agricultural irrigation as the top source of freshwater withdrawals in the U.S. in 2000. ${ }^{1}$ For Americans to preserve their standard of living and maintain a thriving economy it is essential that greater attention be paid to freshwater availability in efforts to meet energy demands-particularly for electric power. According to projections by the Energy Information Administration's (EIA) Annual Energy Outlook 2006 (AEO 2006) anticipated growth of thermoelectric generating capacity will be 22\% between 2005 and 2030. ${ }^{2}$ In the 2007 Report, EIA estimates that capacity to grow from approximately $709 \mathrm{GW}$ in 2005 to $862 \mathrm{GW}$ in $2030^{3}$. These large increases in generating capacity will result in increased water demands by

\footnotetext{
${ }^{1}$ U.S. Geological Survey. Estimated Use of Water in the United States in 2000; USGS Circular 1268; March 2004.

2 Energy Information Administration, Annual Energy Outlook 2006 with Projections to 2030, http://www.eia.doe.gov/oiaf/aeo/index.html, February 2006.

${ }^{3}$ Energy Information Administration, Annual Energy Outlook 2007. 2008. Report Number

DOE/EIA-0383(2008). March (Revised)
} 
thermoelectric power plants and greater competition over water between the energy sector and domestic, commercial, agricultural, industrial, and instream use sectors. The implications of these increased demands have not been adequately researched. This report is a preliminary effort to explore these implications.

In addition, since this report was completed in draft form in 2007, there have been several updates and important issues brought to bear on water for energy that should be mentioned. Uncertainties include drought and climate change impacts. Policies such as commitments to Coal-to-Liquids (CTL) quotas; Ethanol production requirements; Carbon Capture and Storage (CCS) mandates; increasing nuclear power plant construction; valuing carbon and carbon dioxide emissions all have significant implications on water use and on the need for water in the power sector by 2025. 


\section{INTRODUCTION}

The purpose of this report is to estimate the likely availability of freshwater for additional thermoelectric generation in twelve states within the region encompassed by the Southern States Energy Board (SSEB). The SSEB states that the report evaluates are: Alabama, Arkansas, Florida, Georgia, Kentucky Louisiana, Maryland, Mississippi, North Carolina, Oklahoma, South Carolina, Tennessee, Texas, Virginia, and West Virginia.

Thermoelectric power plants - coal, oil, natural gas and nuclear-fueled power generators - require vast quantities of water for steam generation and cooling. For example, a 500MW coal-fired power plant burns approximately 250 tons per hour of coal while using over 12 million gallons of water per hour for cooling turbine exhaust. ${ }^{4}$

As both regional population and economic development continue to grow, the demand for energy and viable water sources will too continue to increase. This growth will inevitably increase the amount of water used by thermoelectric generation plants. The EIA's latest forecast estimates U.S. thermoelectric generating capacity will grow from approximately $709 \mathrm{GW}$ in 2005 to $862 \mathrm{GW}$ in $2030 .^{5}$ A large portion of this growth in demand is projected to occur in the southeastern region of the U.S.

According to the U.S. Census Bureau, the southeast is the fastest-growing region in the nation $^{6}$. The Southeastern Energy Efficiency Alliance found that in 2001, over 511 thousand privately-owned housing permits were issued to residents of the southeastern region - or 31\% of the nation's total permits given to all regions that year. Along with growing population, the region has a growing energy demand (see Figure 1). The Federal Energy Regulatory Commission found that the southeast has the highest per capita electricity consumption of any region in the nation. ${ }^{7}$ Three southeastern states - Florida, Tennessee and Texas - are among the largest total (i.e., freshwater and saline water) withdrawers of water for thermoelectric power generation. Texas leads the nation in total withdrawals for this purpose (in 2000, 14.9 million acre-feet per year). ${ }^{8}$

It is evident that the southeast's current rate of growth will impose additional energy demands for the region. Accompanying the certainty of this growth, many questions will arise surrounding available supply and probable demands for the water necessary to support the process of thermoelectric generation. Current and future water-related issues

\footnotetext{
${ }^{4}$ Power Plant Water Consumption Study, Michael G. Klett, Norma J. Kuehn, Ronald L. Schoff, Vladimir Vaysman, Jay S. White, U.S. Department of Energy, National Energy Technology Laboratory, August 2005. http://www.netl.doe.gov/technologies/coalpower/gasification/pubs/pdf/WaterReport IGCC Final Agust2005.pdf

${ }^{5}$ Energy Information Administration. Annual Energy Outlook 2007, EIA Report No. DOE/EIA0383(2008). March (Revised)

${ }^{6}$ U.S. Census Bureau, Projected Population Increases, October 1996

${ }^{7}$ Southeastern Energy Efficiency Alliance, http://www.seealliance.org/why-e-e-se.html, 2006

${ }^{8}$ Susan S. Hutson, Nancy L. Barber, Joan F. Kenny, Kristin S. Linsey, Deborah S. Lumia, and Molly A. Maupin. 2000. Estimated Use of Water in the United States in 2000. U.S. Geological Survey Circular 1268. Denver, CO, p. 36. Florida, at 14.1 million acre-feet per year ranked $3^{\text {rd }}$ nationwide, while Tennessee was tied with New York at $7^{\text {th }}$ (10.1 million acre-feet per year).
} 
and constraints will impact the availability and efficiency of water sources. In addition, environmental regulations and requirements, regional hydrological constraints (including the possibility of climate change and variability - e.g., periodic drought), and societal and economic restrictions (e.g., siting issues, costs) are sure to challenge the freshwater availability and operation of thermoelectric generation projects.

Figure 2 (Energy Consumption by sector through 2030) and Figure 3 (listed as figure 7 from the Energy Information Administration -Electricity Generation by fuel source through 2030) indicate the magnitude of growth in the use and production of electricity over the next twenty-plus years. While renewables continue to grow, the forecast for increases in generation from central-station electrical generators is significant and, as such, the water use implications of this increased generation must be reviewed. ${ }^{9}$

Figure 1 : Projected Population Increase

Of Energy Efficiency Alliance Regions 2005 to 2025

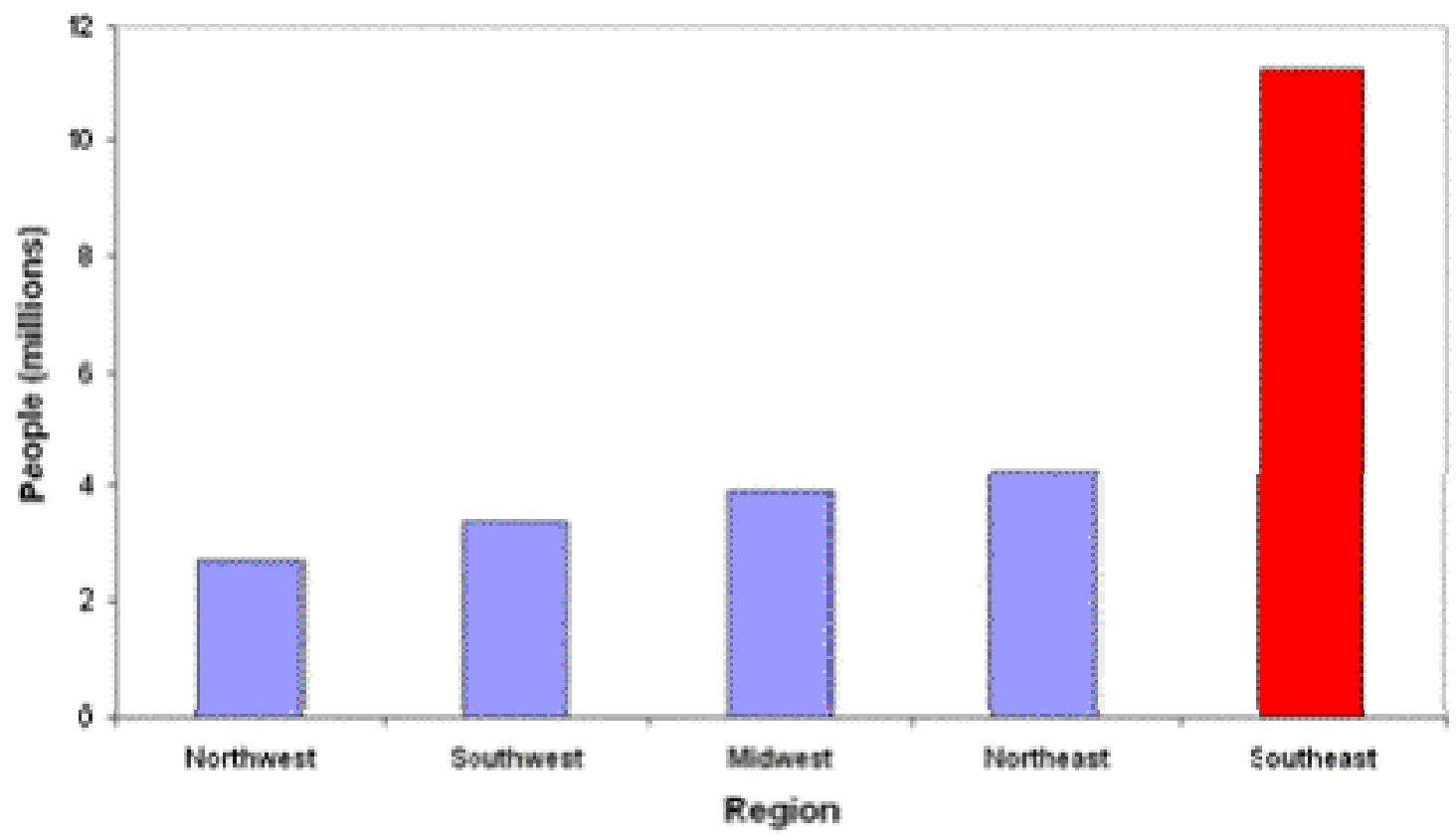

Source: U.S. Census Bureau, Projected Population Increases, October 1996

\footnotetext{
${ }^{9}$ Energy Information Administration. Annual Energy Outlook 2007, EIA Report No. DOE/EIA0383(2008). March (Revised)
} 
Figure 2. Delivered energy consumption by sector, 1980-2030 (quadrillion Btu)

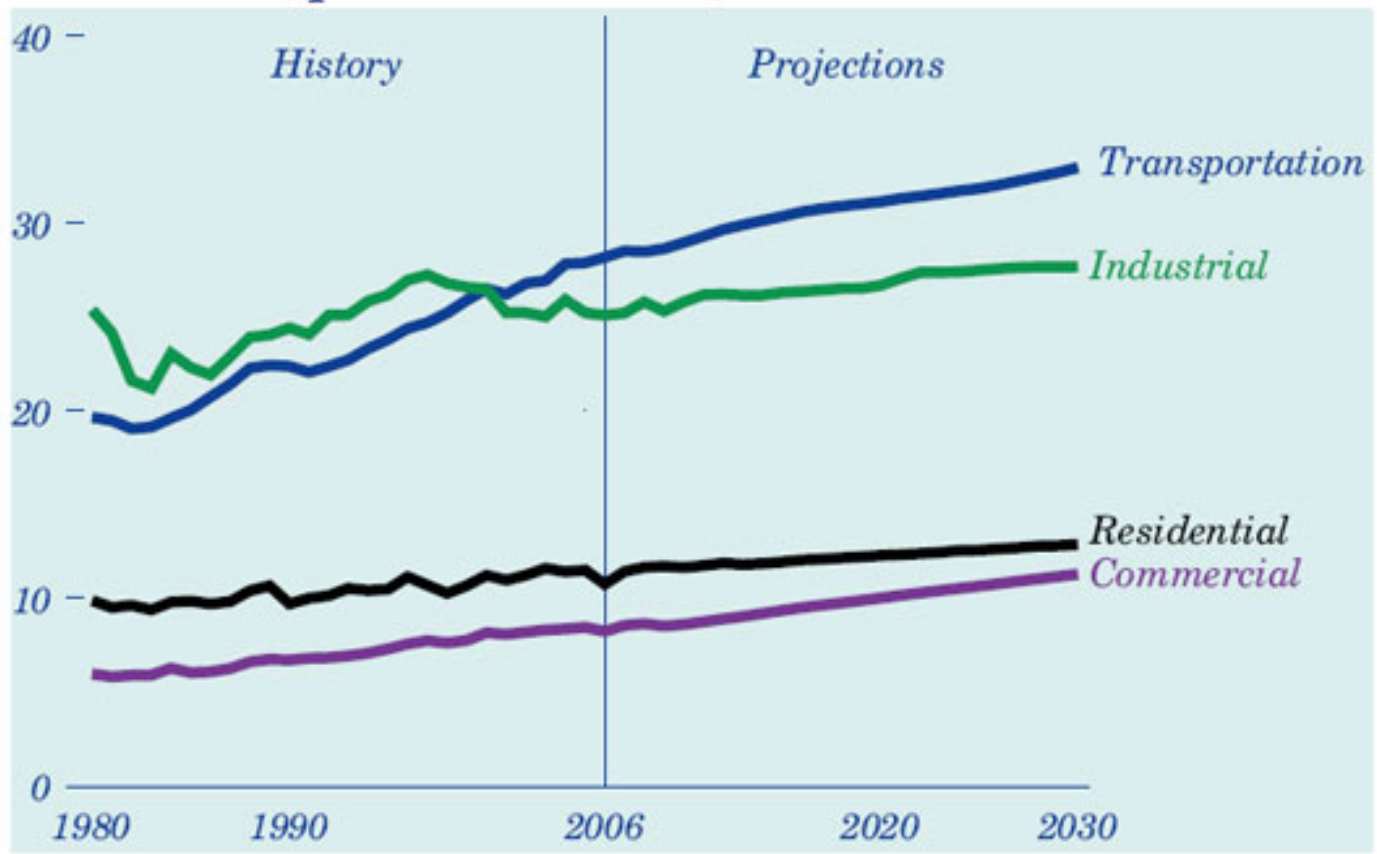

Figure 7. Electricity generation by fuel, 1980-2030 (billion kilowatthours)

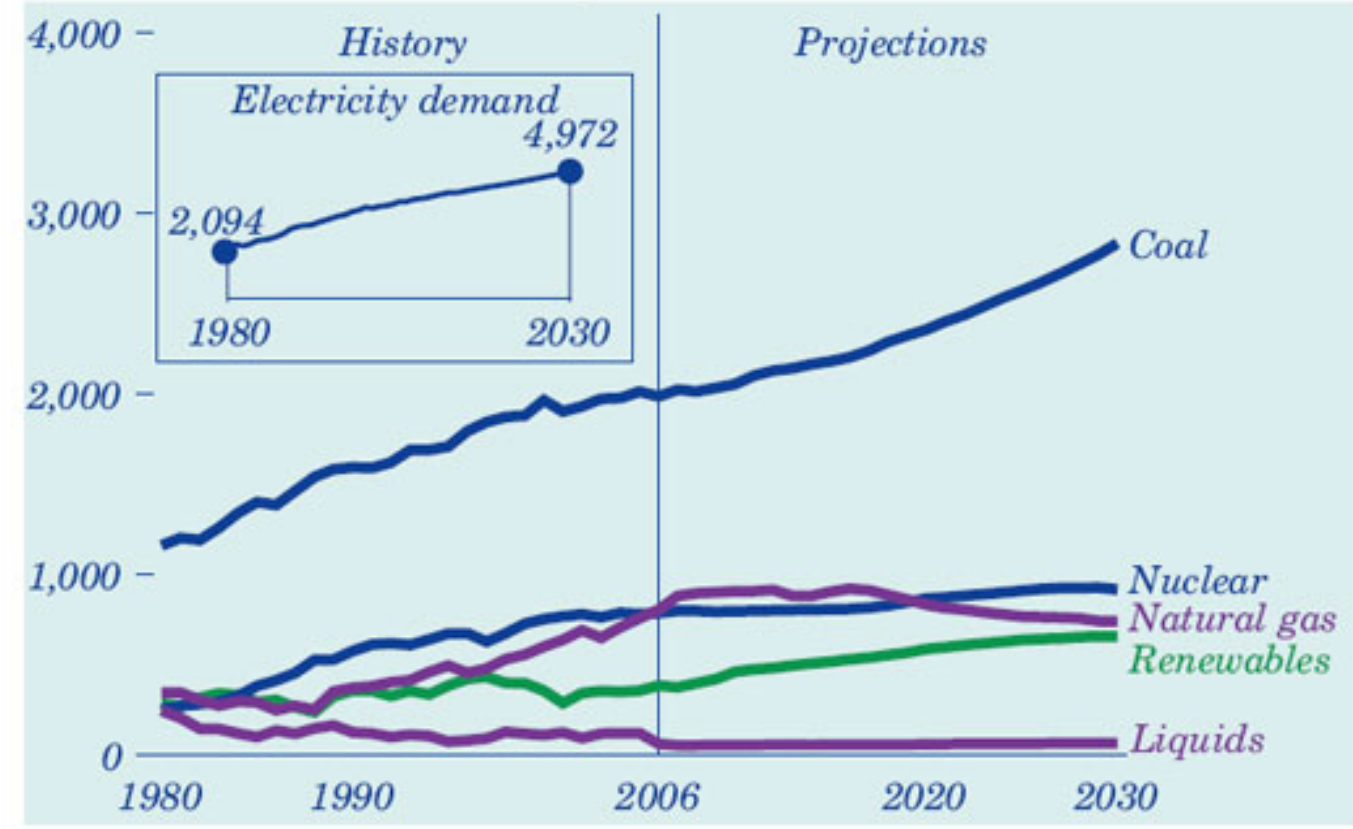

Figure 3. Electricity Generation by Fuel, 1980-2030 (Billion of Kilowatthours) 


\section{Baseline Water Usage}

In the NETL update, forecasts of future freshwater withdrawal and consumption requirements for the U.S. thermoelectric generation sector were estimated for five cases using the AEO 2007 regional projections for capacity additions and retirements. By 2010, withdrawals are expected to increase from 146.6 billion gallons per day in 2005 up to 149.9 billion gallons per day or even decrease to 140.9 , depending on scenarios. The cases (1-5) represent scenarios describing different addition and retirement assumptions; use of freshwater and wet re-circulating cooling systems; proportions of dry cooling systems; and combinations of each. For all but the first case, withdrawals are expected to decline and consumption for all five cases is expected to increase. The most important result can be seen in the next figure (Figure 4) which shows, by regional reliability corporation, the average daily freshwater withdrawals expected for thermoelectric power generation for 2005 and the incremental withdrawals through $2030 .^{10}$ Note the SERC Reliability Corporation, which is entirely located within the Southern States Energy Board territory, ERCOT (majority of Texas), FRCC (Florida) data, since they represent the majority of the SSEB region. Note withdrawals in SERC for a 'moderate', representative case (Case 2), are around 45 Billion gallons per day.

Table 1 - Freshwater Withdrawal or Consumption (Billion gallons per day)

\begin{tabular}{|c|c|r|r|r|r|r|r|}
\hline \multirow{2}{*}{} & \multicolumn{6}{|c|}{ Freshwater withdrawal or consumption (BGD) } \\
\cline { 3 - 8 } \multicolumn{2}{|c|}{} & $\mathbf{2 0 0 5}$ & $\mathbf{2 0 1 0}$ & $\mathbf{2 0 1 5}$ & $\mathbf{2 0 2 0}$ & $\mathbf{2 0 2 5}$ & $\mathbf{2 0 3 0}$ \\
\hline \multirow{2}{*}{ Case 1} & Withdrawal & 146.6 & 149.9 & 144.6 & 151.2 & 154.9 & 155.4 \\
\cline { 2 - 8 } & Consumption & 3.7 & 3.9 & 4.1 & 4.5 & 4.9 & 5.3 \\
\hline \multirow{2}{*}{ Case 2} & Withdrawal & 146.6 & 146.9 & 141.0 & 141.6 & 141.9 & 141.3 \\
\cline { 2 - 8 } & Consumption & 3.7 & 4.0 & 4.2 & 4.7 & 5.2 & 5.7 \\
\hline \multirow{2}{*}{ Case 3 } & Withdrawal & 146.6 & 146.8 & 140.9 & 141.5 & 141.7 & 141.1 \\
\cline { 2 - 8 } & Consumption & 3.7 & 4.0 & 4.2 & 4.6 & 5.1 & 5.5 \\
\hline \multirow{2}{*}{ Case 4 } & Withdrawal & 146.6 & 146.6 & 140.7 & 141.0 & 140.9 & 140.1 \\
\cline { 2 - 8 } & Consumption & 3.7 & 3.9 & 4.1 & 4.5 & 4.9 & 5.2 \\
\hline \multirow{2}{*}{ Case 5 } & Withdrawal & 146.6 & 140.9 & 128.9 & 124.3 & 119.7 & 114.4 \\
\cline { 2 - 8 } & Consumption & 3.7 & 4.1 & 4.4 & 4.9 & 5.5 & 6.0 \\
\hline
\end{tabular}

${ }^{10}$ DOE/NETL. Estimating Freshwater Needs to Meet Future Thermoelectric Generation Requirements: 2007 Update. 2007. DOE/NETL 400/2007/1304. 24 September. 
Figure 4. Average Daily Regional Freshwater Withdrawal for Thermoelectric Power Generation - Typical Case (2)

*Note: Blue represents water withdrawal in 2005;

Purple represents incremental water withdrawal 2005-2030.

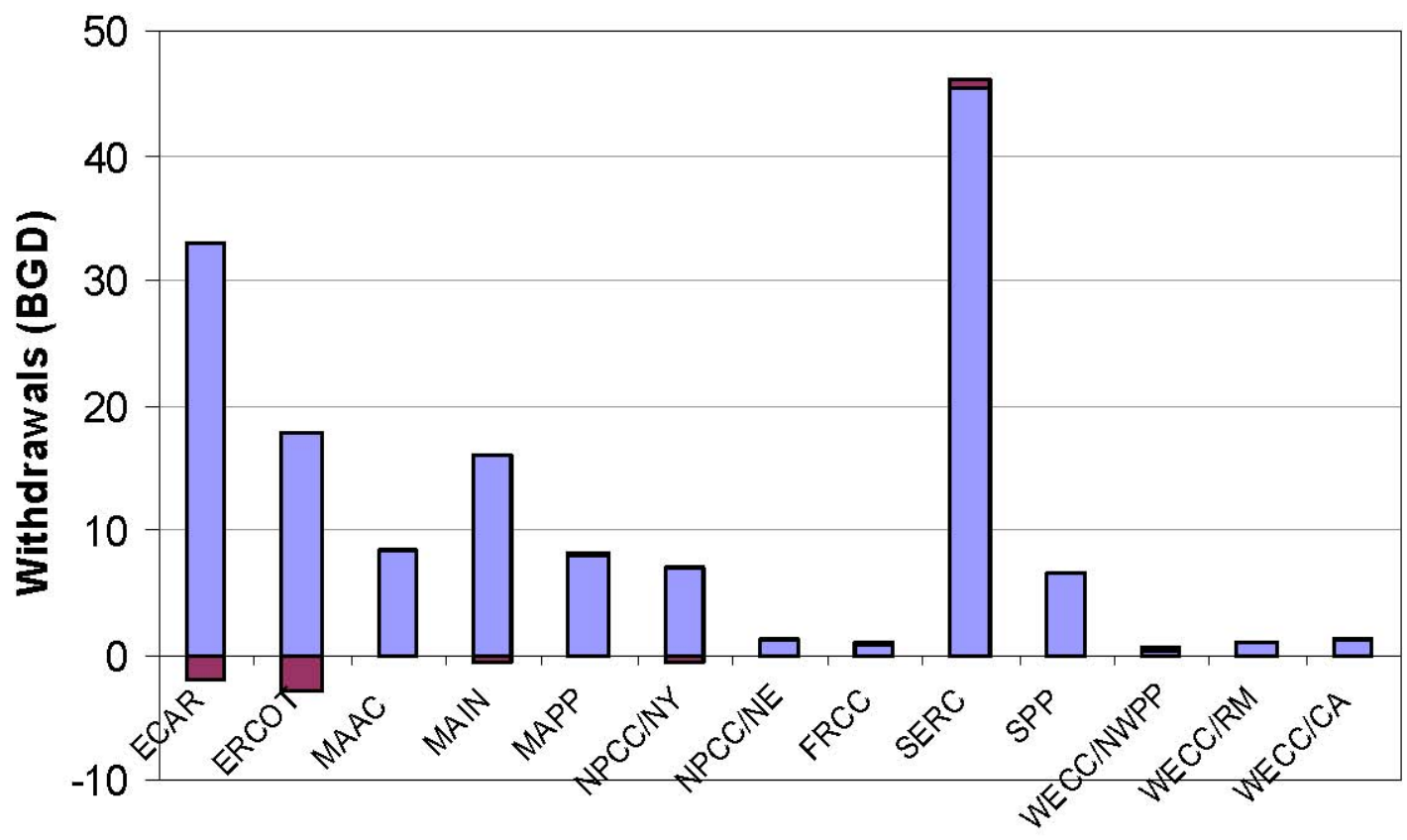

\section{CONSTRAINTS - HYDROLOGIC, SOCIETAL, ECONOMIC, AND POLICY}

There are numerous constraints limiting the supply and availability of freshwater for use in thermoelectric generation. Within the southeastern region each state experiences its own constraints upon available freshwater resources. States are susceptible to freshwater shortages for a multitude of reasons including drought conditions, growing population, and increasing electrical and water demand. For purposes of this report, possible constraints affecting the region fall into one of four categories: hydrologic, societal, economic, and policy constraints.

\section{Hydrologic Constraints}

Hydrologic constraints for thermoelectric generation are those factors that limit or restrict the availability and use of water necessary for heating (steam generation) and cooling processes. Among the hydrological constraints southeastern states will encounter that can hinder access to freshwater for thermoelectric generation are the following:

\section{Ground water depletion}

In much of the southeast, as elsewhere, groundwater is a major source of drinking water and public supply, and is widely used by the agriculture sector for irrigation throughout 
parts of Alabama, Florida, Georgia, Mississippi, Oklahoma, Texas, and many other areas. Groundwater is also a major source of supply for other economic sectors including manufacturing and, of course, energy production (e.g., petroleum refining). According to the USGS, groundwater provides about half of the population of the U.S. with their drinking water and over 50 billion gallons of water per day support the Nation's agricultural economy. ${ }^{11}$ The primary cause of groundwater depletion is sustained groundwater pumping. One important negative effect of groundwater depletion is an increase in pumping costs. This is a result of the water level in a well becoming lower, requiring more energy and, thus, money to drive the pump.

\section{Water quality degradation - including groundwater}

Another problem associated with the depletion of groundwater is deterioration of water quality. This can be due to minerals or pollutants being introduced through the pumping process or from saltwater contamination through intrusion of seawater into an aquifer. This is especially a problem in coastal aquifers because zones of saltwater often lie beneath the drinkable freshwater layer. Under natural conditions, the boundary separating freshwater and saltwater is reasonably stable. However, the action of pumping and extracting the freshwater for use in thermoelectric generation can cause the saltwater to drift inland, resulting in saltwater intrusion. This problem is not confined to coastal areas of the southeast, but is also found in inland aquifers. Freshwater withdrawal from the upper or so-called "cleaner" parts of inland aquifers can also permit the underlying saline water to move upward. This will also degrade groundwater quality.

An additional way freshwater degradation occurs when groundwater levels have become too low through over-pumping is when surface water of questionable quality is drawn into the aquifer. The surface water may contain harmful substances or mobilize naturally occurring contaminants in the aquifer. Another harmful effect of groundwater depletion is a decline of water in streams or lakes. The intimate connection between surface and groundwater is greatly affected by groundwater depletion, because groundwater pumping can change interactions and movements between aquifers and the surface water bodies connected to it. These alterations occur through the interception of groundwater flow that releases into the surface water body under natural conditions, or by escalating the rate of water movement from the surface-water body into an aquifer. Though the negative affects of this interaction may take several years to develop, the overall result of either occurrence is a reduction in the flow of surface water.

Another consequence of ground water pumping is the reduction of groundwater levels below the depth that vegetation and wildlife of surface-water bodies need to survive. This can result in the permanent loss of native vegetation and wildlife habitats and lives. $^{12}$ A final adverse affect of groundwater depletion is land subsidence. This is a

\footnotetext{
${ }^{11}$ U.S. Geological Survey. Ground-Water Depletion Across the Nation, U.S. Geological Survey Fact Sheet 103-03, http://pubs.usgs.gov/fs/fs-103-03/ November 2003.

${ }^{12}$ Susan S. Hutson, Nancy L. Barber, Joan F. Kenny, Kristin S. Linsey, Deborah S. Lumia, and Molly A. Maupin. 2000. Estimated Use of Water in the United States in 2000. U.S. Geological
} 
result of "a gradual settling or sudden sinking of the Earth's surface owing to subsurface movement of the earth materials." 13 Subsidence can be caused by many of the earth's natural processes, but According to Galloway, more than $80 \%$ of land subsidence in the U. S. is a result of groundwater withdrawal.

Increased demands for freshwater have contributed to overstressed and depleted aquifers in many southeastern states. The use of large volumes of groundwater by thermoelectric generation power plants could certainly exacerbate this problem, and the problem of overstressed and depleted aquifers will certainly affect the availability of groundwater for energy uses in the future. A number of examples affirm this prognosis.

In Baton Rouge, Louisiana, groundwater pumping increased more than ten times between the 1930s and 1970. This has resulted in approximately 200 feet of groundwater levels decline. The pumping of groundwater has caused aquifers in the area to shift underground. The consequence of such large water-level declines has been saltwater intrusion form the Gulf of Mexico into many Louisiana's aquifers. ${ }^{14}$

Another southeastern state that is being affected by groundwater depletion is Texas. In the growing city of Houston, widespread groundwater pumping has been used to support economic development and population growth. The result has been an approximately 400-foot decline in water-levels. The consequence is extensive land-surface subsidence of almost 10 feet deep. The high level of subsidence is responsible for increased vulnerability to flooding and permanent inundation of some surrounding areas. ${ }^{15}$ Other southeastern states that have been affected by groundwater depletion include Arkansas, Mississippi, and Tennessee. Industrial and municipal users have been pumping the Sparta aquifer since the 1920s. Over the past 80 years, there has been a significant water-level decline in the states of Arkansas, Louisiana, Mississippi, and Tennessee. These sharp declines have raised concerns about sustainability in many of the states, leading Arkansas to declare the condition of the aquifer as "critical." 16

Survey Circular 1268. Denver, CO, p. 36. Florida, at 14.1 million acre-feet per year ranked $3^{\text {rd }}$ nationwide, while Tennessee was tied with New York at $7^{\text {th }}$ (10.1 million acre-feet per year).

${ }^{13}$ Galloway, D.L., Jones, D.R., and Ingebritsen, S.E., eds., 1999, Land subsidence in the United States: U.S. Geological Survey Circular 1182, 177 p.

${ }^{14}$ Galloway, D.L., Jones, D.R., and Ingebritsen, S.E., eds., 1999, Land subsidence in the United States: U.S. Geological Survey Circular 1182, 177 p.

${ }^{15}$ Galloway, D.L., Jones, D.R., and Ingebritsen, S.E., eds., 1999, Land subsidence in the United States: U.S. Geological Survey Circular 1182, 177 p., and Taylor, C.J., and Alley, W.M., 2001, Groundwater level monitoring and the importance of long-term water-level data: U.S. Geological Survey Circular 1217, 68 p.

${ }^{16}$ Susan S. Hutson, Nancy L. Barber, Joan F. Kenny, Kristin S. Linsey, Deborah S. Lumia, and Molly A. Maupin. 2000. Estimated Use of Water in the United States in 2000. U.S. Geological Survey Circular 1268. Denver, CO, p. 36. Florida, at 14.1 million acre-feet per year ranked $3^{\text {rd }}$ nationwide, while Tennessee was tied with New York at $7^{\text {th }}$ (10.1 million acre-feet per year). 
The Memphis, Tennessee, and West Memphis, Arkansas areas rely exclusively on groundwater for their municipal supplies. This makes them one of the largest metropolitan areas in the world that relies solely on groundwater for their civic supply of water. A consequence of their enormous water withdrawals has resulted in a water level decline in the region of approximately 70 feet. This has produced many interstate concerns over continued and increased pumping in the Memphis area. ${ }^{17}$

\section{Surface water Challenges - Consumptive Water Uses}

Consumptive water uses are those that withdraw water from streams, rivers, other surface water bodies or aquifers and do not return them for immediate subsequent use ${ }^{18}$ (thereby making it unavailable for use by others. Unavailability may be due to absorption, evaporation, transpiration or incorporation in a manufactured product or crops, or used by humans or livestock. In some instances, unavailability may occur when water is returned to a stream at a distance downstream from the point of diversion.

In the southeast, consumptive water uses are mainly attributable to agricultural irrigation and, in some instances, fossil or nuclear power plant cooling (particularly where "oncethrough" cooling is used. Total freshwater withdrawals and consumptive uses do not closely correlate. For example, while Tennessee is the largest user of freshwater withdrawals in the southeast (1995) at 10.07 billion gallons per day (BGD), water consumed on average equals 233 million gallons per day (MGD) or approximately 2.3\% of the total withdrawn for all uses. The greatest single consumptive water use in Tennessee is for agriculture. Virtually all the $61 \mathrm{Mgal} / \mathrm{d}$ withdrawn for agriculture in the state is consumed, compared to $11 \%$ of industrial and mining use and $10 \%$ of domestic use (USGS, 1999). In the southeast as a whole, the highest rates of water consumption are found in Mississippi (over 50\%), followed by Florida (38\%), Georgia (20\%), and Virginia (almost 15\%). Most of the freshwater consumed in these three states is by agricultural irrigation and livestock watering.

One sign of relief for the water supply comes, ironically, from the power sector in examples such as the Southern Company Plant McDonough, a coal-fired electric power plant, which has recently installed two new cooling towers. These towers will keep warm water from flowing into the Chattahoochee River from the power plant, making the water less susceptible to degradation. Of course these cooling towers use more river water than they return but the tradeoff is the ability of the river to maintain its water temperature ${ }^{19}$. Prior to the operation of the cooling towers, Plant McDonough withdrew

\footnotetext{
${ }^{17}$ Feldman, David L., and Jill Elmendorf. 2000. Water Supply Challenges Facing Tennessee: Case Study Analyses and the Need for Long-Term Planning. Prepared for the Environmental Policy Office, Tennessee Department of Environment and Conservation, by the Energy, Environment and Resources Center, University of Tennessee. Nashville, Tennessee, June. ${ }^{18}$ Solley, Wayne B., Robert R. Pierce, and Howard A. Perlman. 1998. Estimated Use of Water in the United States in 1995. U.S. Geological Survey. Circular 1200. Denver, Colorado: U.S. Geological Survey.

${ }^{19}$ K. Duffy. "New Towers to Help River Keep Its Cool”. 2008. Atlanta Journal Constitution. 24 February.
} 
an average of 344 million gallons of water per day from the Chattahoochee River. Georgia Power estimates future withdrawals will average less than 20 million gallons per day and return about half of that to the river ${ }^{20}$.

Table 2. Population Growth Rates (1990-2000), Water Uses, and Water Consumption*

\begin{tabular}{||l|r|r|r|r|r||}
\hline \multicolumn{1}{|c|}{ State } & Growth rate \% & Rank & $\begin{array}{c}\text { Freshwater } \\
\text { withdrawn } \\
\text { (1995) BGD* }\end{array}$ & $\begin{array}{c}\text { Total } \\
\text { freshwater } \\
\text { consumed } \\
\text { (1995) MGD* }\end{array}$ & $\begin{array}{c}\text { \% freshwater } \\
\text { consumed } \\
\text { (1995) }\end{array}$ \\
\hline \hline Alabama & 10.1 & 25 & 7.09 & 532.3 & 38 \\
\hline Florida & 23.5 & 7 & 7.21 & 2,780 & 20 \\
\hline Georgia & 26.4 & 6 & 5.75 & 1,170 & 7.2 \\
\hline Kentucky & 9.7 & 28 & 4.42 & 318 & 51 \\
\hline Mississippi & 10.5 & 24 & 3.09 & 1,570 & 713 \\
\hline N. Carolina & 21.4 & 9 & 7.73 & 321 & 5.1 \\
\hline S. Carolina & 15.1 & 15 & 6.20 & 233 & 2.3 \\
\hline Tennessee & 16.7 & 14 & 10.07 & 818 & 14.9 \\
\hline Virginia & 14.4 & 16 & 5.47 & & \\
\hline
\end{tabular}

Sources: U.S. Geological Survey and U.S. Census Bureau (2001). BGD = billions of gallons/day; MGD = millions of gallons/day.

As can be seen in Table 2, the entire region is experiencing dramatic and rapid growth. While this growth most certainly has a significant impact on water demand, the relationship between population growth and water use is not directly linear due to different water uses predominating in each state (e.g., agricultural irrigation vs. power generation and industrial use). In fact, variation in water withdrawn is a consequence of two principal factors in the states shown- agricultural irrigation and thermoelectric generation. The former use is consumptive, while the latter use is not nearly so. This explains why Tennessee leads the region in water withdrawal (most of it is for power generation), while Florida, Georgia, and Mississippi lead the region in amounts consumed through evapo-transpiration.

The persistence of drought conditions gripping parts of the US, especially the southeast, has underscored the need to conserve scarce water resources. The debate has sparked controversy over water consumed by power generating facilities. In fact, drought conditions have led the US Army Corps of Engineers to reduce water flow from Lake

\footnotetext{
${ }^{20}$ Upper Chattahoochee Riverkeeper. “Power Industry and River Flows”. 2008. RiverChat. Atlanta, GA.
} 
Lanier, a reservoir in Georgia that provides a significant portion of metro Atlanta's drinking water, to downstream users such as Southern Company's Farley Nuclear Plant in Alabama and the company's Scholz coal-fired power plant in Florida. Southern Company advised Corps representatives and the governors of Alabama, Florida and Georgia of the flow requirements needed to continue normal plant operations. They also discussed actions that could be taken to operate temporarily under reduced flows. The three governors have continued to meet to further assess the situation ${ }^{21}$.

\section{Desalination}

Desalination, or turning saltwater into drinking water, is one option for a region in which drought conditions or the simple magnitude of growth are creating concerns over the availability of drinking water. Some of the costs involved with desalination include the proper treatment of the salty sludge that is created through the process. Technology is sensitive to sediment and small particles can foul the expensive membranes that filter the salt out of the water. Based on treatment facilities in Tampa, the cost of desalination is between $\$ 3$ - \$3.40 per thousand gallons of water. Other cost estimates suggest prices could be a third of those experienced in Tampa.

The Tampa process consists of three phases. First, raw seawater is filtered and treated to remove particles and solids. Next, this water is pushed through ultra fine membranes under high pressure and finally salt concentrate output is chemically treated to stabilize the water since desalination process also removes minerals.

One significant drawback and rather ironic factor with desalination is that the process requires large amounts of electrical energy - for purification. The power requirements make up about half of the costs of desalination and, in the example of serving the metropolitan region of Atlanta, Georgia with treated water, there would be significant electrical requirements to pump the water from the coast. Water quality also degrades over time and distance, creating inefficiency with respect to the amount of water required to treat other water resources. For the Tampa plant, 1.4 billion gallons of seawater passes through the power plant each day to treat 44 million gallons of seawater per day, producing some 25 million gallons of drinking water and 19 million gallons of salt concentrate $^{22}$.

With this potential need for desalination to provide adequate drinking water supplies in some cases, there is significant research and development ongoing to attempt to reduce the cost of desalination; reduce energy requirements (and therefore the water requirements to treat the saltwater); more effective and efficient methods of disposing of desalination by-products like brine; and how these water withdrawals will affect the environment. Typical desalination plant sizes range from 24-60 million gallons per day

\footnotetext{
${ }^{21}$ Upper Chattahoochee Riverkeeper. "Power Industry and River Flows”. RiverChat. 2008. Atlanta, GA.

${ }^{22}$ K. Foskett. “Desalination is Costly, Challenging”. 2008. Atlanta Journal Constitution. 17 February.
} 
and even though the theoretical concepts suggest $0.86 \mathrm{kwh}$ of electricity should be able to treat 1 cubic meter of salt water (35,000 ppm), current plants use about 5 to 25 times as much energy as the theoretical need ${ }^{23}$.

\section{Societal Constraints}

Regulations addressing freshwater quality and effluent are becoming more stringent over time. Growing concerns over the effects of water management and water quality on public health have generated new societal constraints for the use of freshwater in the thermoelectric generation process. Citizens understand the importance of clean freshwater to sustain a healthy community. The freshwater contamination that is an occasional result of groundwater pumping is an aspect of thermoelectric generation that many citizens may oppose. The possibility of contamination of municipal water supplies is an issue that generates strong public criticism. ${ }^{24}$ Citizens, voters, and elected officials are not likely to support a permit allowing a thermoelectric plant to use the large quantities of water that are necessary to support the process. The hydrological constraints that can affect citizens are a major drawback of the thermoelectric generation process. Freshwater shortages and rivers, streams, lakes, and wetlands drying up can pose many threats to citizens in the southeast. As water sources dry up or become contaminated, people dependent on these resources will be subject to constraints on available supply that will not be easy to mitigate. Though the probability of these extreme events occurring at a given place and time may be minimal or remote, the perceived threat may be sufficient to trigger some citizens and policy-makers to strongly regulate or limit the amount of freshwater available for use by new or expanded thermoelectric generating power plants and other facilities.

Wise management of water resources for energy supplies requires great flexibility and coordination to ensure climate uncertainties will not devastate water supplies. For the southeast U. S. this is an exceptional challenge because many small agencies have minimal jurisdiction on specific areas, and there are places where water resources remain essentially unmanaged. Water resources decisions in the U.S. are many and varied, involve public and private sector decision-makers, and entail multiple spatial scales ranging from local, state, and national levels of decision-making. In addition to embracing many agencies, the spatial scale of decisions made by water management organizations is diverse, ranging from small community water systems to large, multipurpose metropolitan water service and regional water delivery systems. The range of overlapping agencies and organizations at multiple scales is compounded by the complexity of geography. While some entities manage water resources in ways that conform to hydrological constraints (i.e., watershed, river basin, aquifer or other drainage

\footnotetext{
${ }^{23}$ K. Boyle. "Desalination Increasingly Viable Option as Supplies Dwindle. 2008. Greenwire”. 24 April.

${ }^{24}$ For a recent analysis see: Public Agenda, 2006. "Environment: People’s Chief Concerns,” Available at publicagenda.org/issues/pcc_detail2.cfm?issue_type=environment\&concern_graphic=pccenvirow orryRF.jpg, and Walter A. Rosenbaum. 2005. Environmental Politics and Policy, $6^{\text {th }}$ Edition. Washington, D.C.: Congressional Quarterly Press, pp. 58, 171.
} 
basin), basin-scale management is not the most common management approach in the U.S., and there is little national-level integration of water policy. ${ }^{25}$ As shall be seen, a fundamental lack of understanding on how collective water management will respond to climatic or socioeconomic factors at both the local and regional levels is an important issue regarding energy for water use.

As time passes, aging water resources infrastructure will strain to function properly. This is another problem water managers will face in the future. Meeting future demands for water supply and ensuring proper flood management in the case of sudden or dramatic climate change is crucial. An example of where this has already been a problem in the southeast is event of Hurricane Katrina. The outdated water management infrastructure was ineffective at containing the rapid increase in water and resulted in flooding an entire city. Had a competent water management team or official had an operational plan to deal with extreme weather, the excess water could have been dealt with and not caused such devastation for the community.

\section{Economic Constraints}

As the southeast continues to grow, citizens will demand energy and water to support and maintain their lifestyles. The increase in population and energy demands will result in the need for additional energy suppliers. These suppliers, public or private, are likely to encounter some economic constraints associated with thermoelectric generation.

The issue of water resource availability is becoming an increasingly import concern, both in terms of quality and quantity. Increasing numbers of regulations and restrictions are being implemented on every aspect of freshwater withdrawal. These water regulations are beginning to have the central idea of conservation and sustainability. To conserve and sustain the water in the southeastern region limits on water withdrawal and consumption will become the norm, and electricity providers and consumers will have to cope with the new regulations.

The hydrological consequences that result from declining ground-water levels will affect the economic feasibility of thermoelectric power plants. The need for enormous amounts of freshwater for thermoelectric generation will cause the depth to reach groundwater to increase. This in turn will cause the lift distance to increase and the amount of energy

\footnotetext{
${ }^{25}$ Rayner, Steve, Denise Lach, Helen Ingram. 2005. "Weather Forecasts are for Wimps: Why Water Resource Managers do not Use Climate Forecasts,” Climate Change 69: 197-227; Kenney, Douglas S. and William B. Lord. 1994. Coordination Mechanisms for the Control of Interstate Water Resources: A Synthesis and Review of the Literature. Report for the ACF-ACT Comprehensive Study. U.S. Army Corps of Engineers, Mobile District, July; Hutson, Susan S., Nancy L. Barber, Joan F. Kenny, Kristin S. Linsey, Deborah S. Lumia, Molly A. Maupin. 2004. Estimated Use of Water in the United States in 2000. U.S. Geological Survey Circular 1268. Reston, VA: USGS; and, Sarewitz, Daniel and Roger A. Pielke, Jr. 2006. "The Neglected Heart of Science Policy: Reconciling Supply of and Demand for Science,” Environmental Science and Policy.
} 
used to obtain the water will increase as well. Depending on the use of water and the energy costs for acquiring the water and costs of permits, it may not be economically practical to pump for groundwater.

\section{Nuclear Power}

Another potential economic constraint is the changing mix of energy generation options in the region. As of this writing, there remains considerable speculation as to when - or even if $-\mathrm{a}$ 'second nuclear era" will commence in the U.S. In 2005, the nuclear power consortium NuStart Energy named several sites from which it will later pick two for which to apply for licenses to build and operate nuclear power plants - all in the southeastern U.S. Four of the six already house operating nuclear power plants. These sites are: Scottsboro, Alabama, Bellefonte Nuclear Plant, an unfinished site owned by the U.S. government's Tennessee Valley Authority, Port Gibson, Mississippi, Grand Gulf Nuclear Station, owned by Entergy, in St. Francisville, Louisiana, River Bend Station, owned by Entergy, in Aiken, South Carolina, Savannah River Site, a U.S. DOE site in South Carolina, Calvert Cliffs Nuclear Plant, owned by Constellation Energy in Lusby, Maryland, and Nine Mile Point plant, owned by Constellation Energy in Oswego, New York. The consortium will evaluate the sites on 75 factors including seismic activity, availability of water and emergency preparedness issues. Significantly, none of these factors - including water - is thought to be a significant barrier to plant siting and development. ${ }^{26}$

Table 3 is taken from a U.S. Nuclear Regulatory Commission report depicting expected new nuclear power plant applications through April $2008^{27}$. Notably, all but two of the forecast license applications for constructing new plants are inside the SSEB region. Most of the anticipated licenses are to be granted for new plants built at existing nuclear plant sites. We would speculate that reasons for the decision to choose existing sites is to make it easier to ensure available water supply, more easily accommodate the need to augment an existing water quality discharge (NPDES) permit, and comply with other regulatory demands. Table 3 follows.

\footnotetext{
${ }^{26}$ Six sites finalists for nuclear power plants U.S. consortium's list could be step toward renaissance, MSNBC staff and news service reports Updated: 11:15 a.m. ET May 20, 2005. http://www.msnbc.msn.com/id/7921287/.

${ }^{27}$ Nuclear Regulatory Commission. “Expected New Nuclear Power Plant Applications”. 2008. 23 April revision.
} 


\begin{tabular}{|c|c|c|c|c|c|}
\hline \multicolumn{6}{|c|}{$\begin{array}{c}\text { Expected New Nuclear Power Plant Applications } \\
\text { Updated April 23, } 2008\end{array}$} \\
\hline Company * & Design & $\begin{array}{c}\text { Date } \\
\text { Accepted }\end{array}$ & $\begin{array}{c}\text { Site Under } \\
\text { Consideration } \\
\end{array}$ & State & $\begin{array}{l}\text { Existing } \\
\text { Op. Plant }\end{array}$ \\
\hline \multicolumn{6}{|c|}{ Calendar Year (CY) 2007 Applications } \\
\hline Duke $(52-018 / 019)$ & AP1000 & $2 / 25 / 08$ & $\begin{array}{l}\text { William Lee Nuclear Station } \\
\text { ( } 2 \text { units })\end{array}$ & $\mathrm{SC}$ & $\mathrm{N}$ \\
\hline NuStart Energy (52-014/015) & AP1000 & $1 / 18 / 08$ & Bellefonte ( 2 units) & $\mathrm{AL}$ & $\mathrm{N}$ \\
\hline Dominion (52-017) & ESBWR & $1 / 29 / 08$ & North Anna (1 unit) & VA & $\mathrm{Y}$ \\
\hline NRG Energy (52-012/013) & ABWR & $11 / 29 / 07$ & South Texas Project (2 units) & TX & $\mathrm{Y}$ \\
\hline \multicolumn{6}{|c|}{$\begin{array}{c}\text { 2007 TOTAL NUMBER OF APPLICATIONS }=4 \\
\text { TOTAL NUMBER OF UNITS }=7\end{array}$} \\
\hline \multicolumn{6}{|c|}{ Calendar Y ear (CY) 2008 Applications } \\
\hline Progress Energy $(52-022 / 023)$ & AP1000 & $4 / 17 / 08$ & Harris (2 units) & NC & $\mathrm{Y}$ \\
\hline Progress Energy (756) & AP1000 & & Levy County (2 units) & FL & $\mathrm{N}$ \\
\hline $\begin{array}{c}\text { South Carolina Electric \& Gas } \\
(743)\end{array}$ & AP1000 & & Summer (2 units) & $\mathrm{SC}$ & $\mathrm{Y}$ \\
\hline $\begin{array}{l}\text { Southern Nuclear Operating Co. } \\
(755)\end{array}$ & AP1000 & & Vogtle (2 units) & GA & $\mathrm{Y}$ \\
\hline Entergy (745) & ESBWR & & River Bend (1 unit) & LA & $\bar{Y}$ \\
\hline NuStart Energy (52-024) & ESBWR & $4 / 17 / 08$ & Grand Gulf (1 unit) & MS & $\mathrm{Y}$ \\
\hline Exelon (761) & ESBWR & & Victoria County (2 units) & TX & $\mathrm{N}$ \\
\hline UNISTAR (52-016) & EPR & $1 / 25 / 08$ & Calvert Cliffs ( 1 unit) & MD & $\mathrm{Y}$ \\
\hline PPL Generation (763) & $\overline{E P R}$ & & Berwick (1 unit) & PA & $\mathrm{Y}$ \\
\hline AmerenUE (750) & EPR & & Callaway (1 unit) & $\mathrm{MO}$ & $\mathrm{Y}$ \\
\hline UNISTAR (759) & EPR & & Nine Mile Point (1 unit) & NY & $\mathrm{Y}$ \\
\hline Luminant Power (754) & USAPWR & & Comanche Peak (2 units) & $\mathrm{TX}$ & Y \\
\hline Detroit Edison (757) & TBD & & Fermi (1 unit) & MI & $\mathrm{Y}$ \\
\hline Amarillo Power (752) & EPR & & Vicinity of Amarillo (2 units) & TX & UNK \\
\hline Alternate Energy Holdings (765) & EPR & & Bruneau (1 unit) & ID & $\mathrm{N}$ \\
\hline \multicolumn{6}{|c|}{$\begin{array}{c}2008 \text { TOTAL NUMBER OF APPLICATIONS }=15 \\
\text { TOTAL NUMBER OF UNITS }=22\end{array}$} \\
\hline \multicolumn{6}{|c|}{ Calendar Year (CY) 2009 A pplications } \\
\hline Florida Power and Light (763) & AP1000 & & Turkey Point (2 units) & FL & $\mathrm{Y}$ \\
\hline \multicolumn{6}{|c|}{$\begin{array}{l}\text { 2009 TOTAL NUMBER OF APPLICATIONS = } 1 \\
\text { TOTAL NUMBER OF UNITS = } 2\end{array}$} \\
\hline \multicolumn{6}{|c|}{ Calendar Year (CY) 2010 A pplications } \\
\hline Blue Castle Project & TBD & & Utah & UT & $\mathrm{N}$ \\
\hline Unannounced & TBD & & TBD & TBD & UNK \\
\hline Unannounced & TBD & & TBD & TBD & UNK \\
\hline \multicolumn{6}{|c|}{$\begin{array}{c}2010 \text { TOTAL NUMBER OF APPLICATIONS = } 3 \\
\text { TOTAL NUMBER OF UNITS = 3 }\end{array}$} \\
\hline & 2007 & $\begin{array}{l}2010 \text { Total } \\
\text { Total Ni }\end{array}$ & $\begin{array}{l}\text { r of Applications }=23 \\
\text { f Units }=34\end{array}$ & & \\
\hline
\end{tabular}

* Project Numbers/Docket Numbers Yellow - Acceptance Review Ongoing

Blue - Accepted/Docketed 
Another concern with respect to the use of water for electrical generation using nuclear fuel is the clustering effect of the new plant applications. In most cases, utilities are requesting that additional units be added to a site that is already being utilized for nuclear power production. Not only are there electrical transmission implications for this type of 'clustering', there could also be incrementally greater impact on water resources at host sites. If the new units use lower-consumption water technology, the impacts will be mitigated somewhat but this issue will likely create some concern and special care to ensure water supply adequately supports the additional capacity. Closed-cycle cooling (versus once-through cooling in older plants) could reduce the use by some twenty times. Several plants, in addition, rely upon saltwater for cooling and, in fact, Progress Energy's new plant proposal is for the use of 30 to 40 million gallons of saltwater from the sea on a daily basis.

\section{Clean Coal Technologies}

In a 2004 report, researchers at the University of Tennessee investigated the possible impacts of adopting clean coal technologies - including coal liquefaction processes - for water supply in the southeast generally and SSEB states in particular. ${ }^{28}$ This report concluded that the most important potential impact was upon water quality in the region, while the most significant constraint - as far as state regulators and utilities were concerned - was the ways in which water quality regulatory programs, including EPA's Total Maximum Daily Load or TMDL program, as well as non-regulatory tools to achieve national ambient water quality standards (e.g., pollution trading and "offset" programs will affect future power plant siting.

\section{Coal to Liquids (CTL)}

In addition to direct combustion to produce heat and power, coal can be used as feedstock for production of liquid fuels, primarily through liquefaction. Coal to Liquids (CTL) provides opportunities for the U.S.to reduce its petroleum import needs by producing petroleum products such as diesel from domestic coal resources. Even in an 'optimistic' CTL market scenario, production estimates are small compared to total global petroleum market, ranging from $0 \%, 6 \%, 10 \%$ to $20 \%$ of U.S. petroleum market share for varied studies. Forecasts range from less than 1 to over 5 million barrels per day of CTL production in the U.S. Current CTL plants being considered include several in the SSEB region including Mingo County, a 10,000 bpd plant from bituminous coal; Rentech's 10,000 bpd plant in Mississippi; and Synfuels, Inc. lignite facility located in Louisiana. Pilot plants are now in operation in various locations in the country including two in Oklahoma. Internationally, there are plants either operating, under construction or planned in South Africa, China, Indonesia, Australia, among others ${ }^{29}$.

\footnotetext{
${ }^{28}$ Feldman, David L., Jennie R. Caissie, Ole Forsberg, Jeff Dahoda, and Meghan Deford. 2004. Regional Efforts to Deploy Clean Coal Technologies: Impacts and Implications for Water Supply and Quality. A Report to the Southern States Energy Board. August, Southeast Water Policy Initiative, the University of Tennessee.

${ }^{29}$ National Petroleum Council (NPC). Coal to Liquids and Gas: Topic Paper \#18. 2007. NPC Committee on Global Oil and Gas. 18 July.
} 
For coal liquefaction projects, important issues in the region are likely to be water quality issues related to temperature, $\mathrm{pH}$, and overall concentration of effluents at the point of emission (e.g., mercury) whether through air deposition or water. While there is considerable debate over how much coal-fired power plants contribute to the problem of mercury deposition leading to impaired waters, mercury could impose a limiting factor on future permitting of new coal-fired power plants. ${ }^{30}$. Changes in water temperature can cause loss of habitat or growth of harmful organisms. Finally, water used in coal-fired power generation circulates through cooling towers and picks up traces of other elements. As water is cycled through these various processes, properties in the water cause $\mathrm{pH}$ levels to change - which may affect living organisms at the point source of emission (i.e., eutrophication, dissolved oxygen levels) leading to the growth of algal blooms and other environmental problems.

The National Petroleum Council (NPC) report mentions water use as an issue, "particularly in geographical areas with limited water resources.” With conventional cooling systems, CTL processes consume between $5-6$ barrels of water for each barrel of liquid product. The amount of water used by a coal conversion facility depends on conversion technology, cooling technology, type of coal, elevation of facility and the climate at the facility. Use of air cooling in place of water cooling and other dry cooling systems can substantially reduce water requirements to less than1 barrel of water per barrel of product.

CTL plants also use substantial amounts of electricity which effectively increases the amount of water embodied in the final product. Again, the exact amount depends on the technologies used in the generating plant ${ }^{31}$.

\section{Ethanol}

Ethanol production is increasing, mainly to fuel automobiles and to fulfill the requirements of the Energy Independence and Security Act of 2007 which increases the Renewable Fuels Standard to 36 billion gallons of renewable fuels, the majority of which must be advanced biofuels like cellulosic ethanol. By the year 2022, for example, 15 billion gallons will be conventional biofuels; 21 billion gallons advanced biofuels; 16 billion gallons of cellulosic biofuels. Ethanol production in the U.S. is expected to double by 2009 adding 5730 million gallons per year. Plant sizes range from 50 to 100 million gallons per year with some 72 refinement plants under construction in the U.S ${ }^{32}$.

\footnotetext{
30 "Innovative Mercury Removal Technique Shows Early promise - photochemical Process Developed in Federal lab Removes Mercury from Flue Gas.” Techline - National Energy Technology laboratory. August 5, 2003. http://www.netl.dow.gov/publications/presss/2003/tl_mercury_netluv.html

${ }^{31}$ National Petroleum Council (NPC). Coal to Liquids and Gas: Topic Paper \#18. 2007. NPC Committee on Global Oil and Gas. 18 July.

${ }^{32}$ North American Electric Reliability Council (NERC). 2007 Long Term Reliability Assessment: 2007-2016: The Reliability of the Bulk Power System. 2007. P.81. Princeton, NJ. October.
} 
The first pressure on water use for ethanol production is in the irrigation of crops used for feedstock. The primary concern with regard to water availability is how much irrigation will be required that might compete with water used for other purposes. Irrigation accounts for the majority of the nation's 'consumptive' water use. The question of how increased water use will be applied to biofuel crop production depends on crop type, where it is being grown, and other typical agricultural factors. ${ }^{33}$

Water is essential in producing ethanol, particularly in the grinding, liquefaction and fermentation processes. As a rule of thumb, water utilization is 10 gallons per minute for each 1 million gallons of yearly ethanol production. A typical 50 million gallons per year ethanol plant would, therefore, need 500 gallons of water per minute ${ }^{34}$. The amount of water used per gallon of ethanol has declined significantly in recent years. At one time, ethanol plants used over 15 gallons of water per gallon of ethanol; in 2002, water use ranged from less than 1 gallon to 11 gallons per gallon of ethanol, averaging almost 5 gallons of water for each gallon of ethanol produced. Numerous sources peg the use of water at 4-5 gallons per gallons of ethanol, including cellulosic plants.

Ethanol plants require processed water to produce ethanol. Plant wastewater contains organic compounds that must be treated in the ethanol plant or connected to local wastewater treatment facilities. New ethanol plants have zero discharge of wastewater and therefore no longer need to connect to the local wastewater treatment services; thus plants can locate in more rural locations closer to the source of raw materials ${ }^{35}$.

\section{Impacts of Wind Generation on Water Use}

There is some relief expected from a source of renewable power that is anticipated to provide significant levels of power over the next 20-plus years. Wind power does not require the level of water resources consumed by many other kinds of power generation. As a result, it may offer communities in water-stressed areas the option of economically meeting growing energy needs without increasing demands on valuable water resources. Wind energy can also provide targeted energy production to serve critical local water system needs such as irrigation and municipal systems. From "The Wind/Water Nexus Wind Powering America”, for example, estimated water savings in the interior west from wind power are, for a 1,200 MW plant, 3.15 billion gallons of water withdrawals, 1.89 billion gallons of water consumed. For a 4,000 MW plant, those savings go to 10.51 billion gallons withdrawals and 6.31 billion gallons consumption. With wind energy

\footnotetext{
${ }^{33}$ National Academies of Science. Water Implications of Biofuels Production in the United States. 2008. Committee on Water Implications of Biofuels Production in the United States, National Research Council.

${ }^{34}$ D. Keeney and M. Muller. Water Use by Ethanol Plants: Potential Challenges. 2006. Institute for Agriculture and Trade Policy. Minneapolis, MN. October.

${ }^{35}$ H. Shapouri and P. Gallagher. USDA's 2002 Ethanol Cost of Production Survey. 2005. US Department of Agriculture: Agricultural Economic Report Number 841. July.
} 
deployment gradually increasing to $20 \%$ of the nation's electricity supply (by 2030), $16 \%$ of the 4 trillion gallons saved nationwide will be in the southeast ${ }^{36}$.

\section{Total Maximum Daily Load (TMDL)}

In sum, our assessment has not changed in three years. All SSEB member states have approved and developed TMDL programs, and are in various stages of implementing TMDLs for impaired watersheds. These programs will affect permitting and siting processes for all coal-fired power plants in the future, as they currently do - including clean coal technologies.

Three issues that affect the efficacy of pollution trading programs: 1) not all pollutants are tradable; 2) trades are often measured in ratios in order that trade allowances can be adjusted for fate and transport characteristics. These characteristics may vary by pollutant and are subject to other conditions such as temperature, flow rates, and geography; 3) use can also impact the fate and transport of pollutants, especially in the case of diversions of large portions of water for a particular form of consumption.

\section{Policy Constraints}

The immense growth in population and the expectation of continued growth has put southeastern states in positions of cooperation and competition. As populations in the southeast continue to grow, demands on water resources and their management will also grow. With this expansion there are bound to be increasing interstate conflicts over all aspects of water rights including uses, quantity and quality protection, wetland protection, navigation, flood control, watershed protection, and wildlife and fish protection.

A recent policy implemented by Georgia Governor Sonny Purdue is a result of saltwater intrusion due to groundwater pumping from the Upper Floridan Aquifer, which is located along the coast of Georgia and adjacent areas of South Carolina and Florida. The new policy is called "Coastal Georgia Water and Wastewater Permitting Plan for Managing Salt Water Intrusion” (PLAN). An issue arose because of heavy withdrawals from the Upper Floridan Aquifer, which resulted in saline water contaminating the freshwater aquifer. It created elevated chloride concentrations at the northern end of Hilton Head Island, South Carolina due to aquifer properties and withdrawal rates. The implementation of the PLAN was to promote the sustainable use of water of the Upper Floridian Aquifer while supporting the continued growth and development of coastal Georgia.

The PLAN's application ensures that the Upper Floridian Aquifer is properly monitored, groundwater withdrawals on the salt-water plumes are identified, wastewater discharges are managed, a water conservation and reuse plan is implemented, all permits are handled properly, and a buffer zone is created around the t-shaped plume area. Though the PLAN has many criteria that look to be beneficial for the many counties and states involved, the

${ }^{36}$ US Department of Energy/Energy Efficiency and Renewable Energy. 20\% Wind Energy by 2030: Increasing Wind Energy's Contribution to U.S. Electricity Supply. 2008. May. 
limits on water withdrawals and the permit process may limit the availability of freshwater for thermoelectric generation. ${ }^{37}$

Another issue that can create policy constraints is the so-called "water wars" concerning water quantity disputes. There has been a disagreement between Georgia, Florida, and Alabama since the 1980s over the Apalachicola-Chattahoochee-Flint (ACF) river basin and the Alabama-Coosa-Tallapoosa (ACT) river basin, resulting in a so called "tri-state water war”. Recent climatic conditions in the southeastern United States have thrust these states into various degrees of drought. Many southeast water bodies are at the lowest levels ever recorded, and this condition is continuing to worsen as this region's winters become increasingly more mild, summer temperatures steadily increase, and less and less rain falls. The unrelenting weather conditions, growing populations, and increasing water demands has caused immense water quantity issues among the southeastern states.

The water war erupted when the city of Atlanta sought a permit from the Corps of Engineers to retain water 529 million gallons of water each day from the Chattahoochee, Flint, and Coosa Rivers, and store it in Lake Lanier, a primary source of drinking water. Atlanta officials believed this was a necessary and legal method of acquiring adequate quantities of water essential to support their projected population growth. The plan would increase withdrawals from the Chattahoochee and Flint rivers by the year 2010.

The permit request caused great tension among the states, and competition for rights and control of the waterway. Downstream, Alabama and Florida viewed the proposal as a major threat to their own drinking water supply and fish and wildlife habitats. They also feared it would increase pollutants in their water supply due to decreased water flow necessary to dilute and minimize the severity of pollution.

Interstate water disputes such as this are generally resolved through the use of the United States Supreme Court or Congressional allocation. Thus, Alabama and Florida file lawsuits in federal court to prevent to implementation of the Atlanta's plan by the Corps. In 1997, before a ruling was issued, the three states agreed to enter into two separate interstate water Compacts, which would allow each states' governor and a federal appointee to negotiate an allocation system for the ACF. ${ }^{38}$ These two Compacts were the first of their kind in the southeast, and will play an important role in water quantity conflicts among southeastern states in the future. They set a precedent for using traditional law doctrine that has been developed in the United States; Riparian Water Law and Prior Appropriation.

${ }^{37}$ Environmental Protection Division, Watershed Protection Branch, Coastal Georgia Water \&Wastewater Permitting Plan for Managing Salt Water Intrusion, March 2007, http://www.gadnr.org/cws/Documents/Coastal_Permitting_2007.pdf

${ }^{38}$ The National Sea Grant Law Center and Mississippi-Alabama Sea Grant Legal Program, Water Quantity Disputes, http://www.olemiss.edu/orgs/SGLC/8disputes.html, October, 31, 2006. 
However, it is important to note that after approximately 5 years, in 2003 the compacts fell apart and the three states are back to litigation, which will result in the Supreme Court making a judgment. Because this is a landmark case concerning water availability use among southeastern states it essential to understand how water quantity, water wars, Riparian Law, and Prior Appropriation can create policy constraints for water allocation for energy-related purposes. ${ }^{39}$

Table 4 is provided to explain the many options used among southeastern states in regards to their different systems of water rights administration. The Southern Regional Water Program created the chart using information from the U.S. EPA. The chart summarizes the various water rights doctrines of each state, how disputes are settled, relevant regulatory agencies, and other important information.

Table 4 Southeastern States’ Water Rights Information

\begin{tabular}{|c|c|c|c|c|c|c|c|}
\hline State & $\begin{array}{l}\text { Water } \\
\text { Rights } \\
\text { Doctrine }\end{array}$ & $\begin{array}{l}\text { Permit } \\
\text { Required }\end{array}$ & $\begin{array}{l}\text { Buy-Sell } \\
\text { Privileges }\end{array}$ & $\begin{array}{l}\text { Dispute } \\
\text { Settlement }\end{array}$ & Compacts & $\begin{array}{l}\text { Legislative } \\
\text { Statutes }\end{array}$ & $\begin{array}{l}\text { Agency } \\
\text { Responsibility }\end{array}$ \\
\hline AL & Riparian & No & No & Gen Court & $\mathbf{0}$ & None & $\begin{array}{l}\text { Office Water } \\
\text { Resources }\end{array}$ \\
\hline AR & Riparian & No & Yes & Gen Court & $\mathbf{0}$ & None & None \\
\hline$\overline{\text { FL }}$ & Statute & Yes & No & Agency & $\mathbf{0}$ & None & Districts \\
\hline GA & Riparian & Yes & Yes & Gen Court & $\mathbf{0}$ & None & Dept of NR \\
\hline KY & Riparian & Yes & No & GC/Agency & 2 & None & Div Water \\
\hline LA & Riparian & No & Yes & Gen Court & 2 & None & None \\
\hline MS & Permit & Yes & No & Agency & $\mathbf{0}$ & None & Dept of NR \\
\hline NC & Riparian & Yes & Yes & Gen Court & 3 & None & Div. Water \\
\hline OK & Appropriat & Yes & No & GC/Agency & 3 & Yes & $\begin{array}{l}\text { Water } \\
\text { Resources }\end{array}$ \\
\hline SC & Riparian & Yes & No & Gen Court & $\mathbf{0}$ & Yes & $\begin{array}{l}\text { Water } \\
\text { Resources Bd. }\end{array}$ \\
\hline TN & Riparian & No & Yes & Gen Court & 2 & Yes & Dept H\&E \\
\hline TX & Appropriat & Yes & Yes & $\begin{array}{l}\text { GC/ } \\
\text { Agency }\end{array}$ & 5 & Yes & $\begin{array}{l}\text { St. Water } \\
\text { Com. }\end{array}$ \\
\hline
\end{tabular}

Sources: Southern Regional Water Program, Water Quantity and Policy, (2007).

${ }^{39}$ Ruhl, J.B., Water Wars, Eastern Style: Divvying Up the Apalachicola-Chattahoochee-Flint River Basin, Journal of Contemporary Water Research \& Education, Issue 131, P. 47-54, June 2005, http://www.ucowr.siu.edu/updates/131/10 ruhl.pdf. 


\section{Permits for Freshwater Withdrawals}

The thermoelectric power industry has many regulations passed by local, state, and federal agencies pertaining to water acquisition, use, and quality. Governments have enacted laws that require major water users to report water withdrawals made within a specified boundary. The information provides an environmental baseline for unified approach to managing water resources and mitigating the effects of possible water availability constraints. These laws and permits also strengthen the legal basis for opposing unwanted or unsafe activities.

\section{National Pollutant Discharge Elimination System (NPDES)}

The NPDES permit was initiated by Clean Water Act and The Federal Water Pollution Control Act amendments of 1972. The purpose of the permit is to impose limitations to help control the discharge of harmful pollutants into surface water and protect the environment. Those that must obtain an NPDES permit is anyone, including power companies whose actions include discharging waste or wastewater into surface waters. All states comprising the Southeastern States Energy Board are fully authorized and approved to use the State NPDES Permit Program and approved to regulated federal facilities discharging waste. ${ }^{40}$

\section{Clean Water Act, Section 316(b)}

According to the U.S. Environmental Protection Agency the Clean Water Act, Section 316(b) was established to ensure the location, design, construction, and capacity of cooling water intake structures are made of the most advanced, environmentally safe technology available. The specific language says:

316 (b)Any standard established pursuant to section 301 or section 306 of this Act and applicable to a point source shall require that the location, design, construction, and capacity of cooling water intake structures reflect the best technology available for minimizing adverse environmental impact.

Cooling water intake structures used for thermoelectric generation often has adverse environmental impacts on fish and wildlife, thus this law was enacted to help alleviate the problems caused by heat, physical stress, and chemicals used to clean the cooling systems. There are three phases to 316(b). Phase I was publicized in 2001, and covers all new facilities. Phase II began in 2004, and it covers all large existing electric generating plants. The final phase, phase III, promulgated in 2006, impacts existing

\footnotetext{
${ }^{40}$ United States Environmental Protection Agency, National Pollutant Discharge Elimination, http://cfpub.epa.gov/npdes/. February 1, 2007.
} 
facilities and new offshore and coastal oil and gas extraction facilities. Section 316(b) often coordinates with the NPDES permitting program. ${ }^{41}$

There is the potential for retrofit requirements for most existing electric generating units, based on a current U.S. Federal Appeals Court ruling. The Department of Energy has estimated that retrofitting cooling towers to a fossil or nuclear electric generating plant would result in a loss of net generation output of 2.5 to 4.0 percent during summer peak load periods. Considering that there are over 440,000 MW of generating capacity in the U.S. using once-through cooling systems, retrofitting could result in a reduction of nearly 18,000 MW in the US, a 12 percent reduction in available capacity margin. Besides derating the capacity, costs of retrofitting cooling towers for many older plants may be prohibitive and some may be retired ${ }^{42}$.

\section{Permit Compliance System}

The Permit Compliance System was developed to provide information on companies, which have been issued permits to discharge waste water into surface water.

\section{Climate Change Effects on Freshwater Availability}

Changes in climatic conditions in the southeastern United States have prompted serious concern over the potential consequences to the region's ecological systems and water supplies. While the range, magnitude, and locality of these effects are open to debate there is increasing evidence that proves the sensitivity and vulnerability of natural systems and water sources in the southeast is due to climate change. Because water resources are the primary element of almost all environmental and socioeconomic activities, they are key components in the overall assessment of how climate change will affect the southeast's future freshwater availability.

The southeast region faces many climatic issues that can cause problems with water availability because it has many interior areas, as well as coastal areas. Problems for interior lands include groundwater contamination, loss of riparian territories, and aquifer subsidence. Each of these damages the availability of freshwater for drinking and for thermoelectric generation purposes. For the southeast's coastal lands, saltwater intrusion is a problem associated with overusing groundwater. This is often a result of low rainfall and drought conditions that are not able to replenish groundwater reserves adequately or quickly enough to prevent saltwater intrusion.

Changes in temperature, precipitation levels, and snowmelt dramatically impact water availability. Increases in annual precipitation levels and the extremity of both floods and droughts can provide important information on how water resources will respond to

\footnotetext{
${ }^{41}$ United States Environmental Protection Agency, Cooling Water Intake StructuresCWA 316(b), http://www.epa.gov/waterscience/316b/basic.htm, December 1, 2006.

${ }^{42}$ North American Electric Reliability Council (NERC). 2007 Long Term Reliability Assessment: 2007-2016: The Reliability of the Bulk Power System. 2007. Princeton, NJ. October.
} 
future variations in climate. Extreme weather events, such as drought, flood, hurricanes, and tornados are indicators for water availability. In the report U.S. National Assessment of the Potential Consequences of Climate Variability and Change, Patrick Mulholland and Katherine Jacobs identify five issues that may affect freshwater availability in the southeast, including: (1) uncertainty in future climate scenarios at both the regional and sub-regional levels; (2) uncertainty in the evapotranspiration and societal response to changes in climate; (3) uncertainty concerning the ability of water resources management organizations to deal with climate changes; (4) aging water resources management infrastructure; and (5) water quality stresses that may occur due to climatic extremes and a lack of ample monitoring to identify intermittent changes in water quality. Each of these issues will affect future freshwater supplies. ${ }^{43}$ Ultimately, it will come down to monitoring the interactive effects of climate and freshwater availability to determine the accessibility for thermoelectric generating power plants.

Climate variability and change can affect water quality in several ways. In general, warmer surface-water temperatures and lower flows tend to have a negative impact through decreases in dissolved oxygen (DO). In contrast, decreased flows to receiving water bodies - especially estuaries and costal waters — can improve water quality, while increased flows can degrade water quality of the receiving water bodies, particularly if they carry increased total loads of nutrients and sediments.

Increased runoff and flooding in urbanized areas can lead to increased loads of nonpointsource pollutants, such as pesticides and fertilizer from landscaped areas, and pointsource pollutants, from the overflow of combined sewer systems. In addition to increasing pesticide and nutrient loads, increase in runoff from agricultural lands can lead to greater sediment loads from erosion and pathogens from animal waste. Loads of nonpoint pollution may be especially large during flooding if the latter occurs after a prolonged dry period in which pollutants have accumulated in the watershed. ${ }^{44}$

Another challenge caused by climate change is likely to be an exacerbation of the previously discussed challenge of groundwater depletion - the effects of which will depend in the Southeast on several factors. In general, the larger and deeper the aquifer, the less inter-annual climate variability will impact groundwater supplies. On the other hand, shallow aquifers that are hydraulically connected to surface waters tend to have shorter residence times and therefore respond more rapidly to climate variability. During

\footnotetext{
${ }^{43}$ Mulholland, Patrick, and Jacobs, Katherine, US National Assessment of the Potential Consequences of Climate Variability and Change U.S. Climate Forum; Water Availability \& Quality: Summary, US Global Change Research Program, http://www.usgcrp.gov/usgcrp/nacc/background/meetings/forum/water_summary.html, October 12, 2003.

${ }^{44}$ J. Furlow. 2006. "The future ain't what it used to be;" climate change and water resources management. Water Resources IMPACT, 8(5): 5-7; Chang, H., B.M. Evans and D.R. Easterling, 2001. Potential effects of climate change on surface-water quality in North America. Journal of the American Water Resources Association, 37(4): 973-985; and, Dorner, S.M., W.B. Anderson, R.M. Slawson, N. Kouwen, P.M. Huck. 2006. "Hydrologic Modeling of Pathogen Fate and Transport,” Environmental Science and Technology 40(15): 4746-4753.
} 
drought, water tables in unconfined aquifers may drop because of reduced recharge and increased pumping rates.

Municipal supply and irrigation wells - such as those in the Memphis, Tennessee area, tend to be developed in larger aquifers and at depths greater than wells supplying individual domestic users. Therefore, they are in general less vulnerable to climate variability. In addition to the reduction in the yield of water-supply wells, drops in water table depths during droughts may result in the drying of springs and worsening of low flow conditions in streams. Greater withdrawals may result because of the shifting of usage from depleted surface waters, as well because of an overall increase in demand due to lower precipitation and greater evapotranspirative demand from the land surface and water bodies.

When long-term average pumping rates exceed recharge rates the aquifer is said to be in overdraft. The karst Edwards Aquifer in south-central Texas, which supplies over 2 million people in the San Antonio metropolitan area, is particularly vulnerable to climate change and variability because it is subject to highly variable rates of recharge and has undergone a steady increase in pumping rates over the last century. ${ }^{45}$ While groundwater overdraft is most common in the arid and semi-arid western U.S., it is not uncommon in the more humid east. ${ }^{46}$

A policy consideration with respect to Coal-to-Liquids production is the potential for water use reallocation, especially if located in a drought area. In some legislation there is consideration for Coal-to-liquids mandates (say 21 billion gallons of CTL by 2022) that will substantially impact water use in the nation. Assuming water use is 5-6 times the production output, the national water impact could be in the neighborhood of 100 billions gallons of water in $2022^{47}$. This could create serious water allocation decision-making in a period of already tight water supply.

To produce the stated national biofuel goal of some 35 billion gallons over the next 10 years creates a strain on water supplies as well. These pressures will come not just from processing but also in the use of water to grow corn and other cellulosic crops for feedstock. In the southeast, a number of cellulosic plants are planned or have become operational including such facilities as the Soperton, Georgia, Range Fuels plant that will produce around 100 million gallons of cellulosic ethanol annually, produced from wood

\footnotetext{
${ }^{45}$ Loáiciga, H.A., 2003. Climate Change and Ground Water. Annals of the Association of American Geographers 93 (1), 30-41.

${ }^{46}$ See for example, Roy, S.B., Ricci, P.F., Summers, K.V., Chung, C.-F., and Goldstein, R.A., 2005. Evaluation of the Sustainability of Water Withdrawals in the United States, 1995-2025. Journal of the American Water Resources Association, 41(5):1091-1108; also, Hurd, B.H., N. Leary, R. Jones, and J.B. Smith, 1999. Relative Regional Vulnerability of Water Resources to Climate Change. Journal of the American Water Resources Association 35(6):1399-1410.

${ }^{47}$ National Petroleum Council (NPC). Coal to Liquids and Gas: Topic Paper \#18. 2007. NPC Committee on Global Oil and Gas. 18 July.
} 
waste as a fuel source. The cellulosic plant should use about a fourth of the water required for a corn-based ethanol facility ${ }^{48}$.

\section{Carbon Capture \& Storage}

The U.S. Department of Energy, along with other national and international entities, both private and public, has a significant demonstration project underway in the United States to help develop the technology, infrastructure and regulations to implement and commercialize large-scale CO2 sequestration in different regions throughout the nation and in different geologic formations. Collectively, seven regional partnerships in the DOE project represent regions encompassing 97 percent of coal-fired CO2 emissions, 97 percent of industrial CO2 emissions, 96 percent of the total land mass, and essentially all the geologic sequestration sites in the U.S. potentially available for carbon storage.

In the southeast region of the country, the Southeast Regional Carbon Sequestration Partnership (SECARB) is active in eleven states including Alabama, Arkansas, Florida, Georgia, Louisiana, Mississippi, North and South Carolina, Tennessee, Texas and Virginia, along with portions of Kentucky and West Virginia. SECARB efforts are focused on four diverse field tests comprised of phases aligned with project definition, design, implementation, operations, and closure: continued characterization of regional sequestration opportunities; and cross-cutting services in education and outreach, regulatory and permitting, monitoring measurement and verification; geographical information systems and project management. The field tests include:

- Two coal seam projects for validation of sequestration opportunities in the Black Warrior Basin Central and the Appalachian Basin, where CO2 Enhanced Coal Bed Methane recovery operations can add economic value and where unmineable coals can provide sequestration opportunities;

- The Mississippi test site is focusing on validation of geologic storage in a deep, saline reservoir. The test is being conducted at Mississippi Power Company's Victor J. Daniel, Jr. power plant, a coal-fired facility near Escatawpa, Mississippi;

- A Gulf Coast Stacked Storage project building upon the Gulf Coast Carbon Center of The University of Texas Bureau of Economic Geology's experience managing the Frio Basin Project and is investigating a stacked sequence of hydrocarbon and brine reservoir intervals, where enhanced oil recovery (EOR) with $\mathrm{CO} 2$ can serve as an economic driver in establishing the $\mathrm{CO} 2$ infrastructure for transportation and storage into underlying deep saline formations.

Current schedules call for the demonstration phase of these DOE tests to begin soon and to be completed within the next 3-10 years. Full deployment of CCS technology on a commercial scale may not occur until some ten years from now; however, the impact of CCS technology being available to offset CO2 emissions will be key to further development of coal fired generating plants as well as to retrofit existing plants so that CO2 emissions can be mitigated.

\footnotetext{
${ }^{48}$ US Department of Energy/Energy Efficiency and Renewable Energy. "Range Fuels Breaks
} Ground on Commercial Cellulosic Ethanol Plant”. 2007. EERE Network News. 7 November. 
Impacts on water use at thermoelectric power plants are threefold. One, the capture of $\mathrm{CO} 2$ to be injected into the caverns beneath power plants or to be transported to suitable storage locations is currently expected to increase the amount of station service for power plant operation. Efficiency of the power plant will, accordingly, go down and the net effect is to increase water supplies needed for the same power output. Second, the southeast region has an abundant storage capability so that power plants with carbon capture capabilities are more likely to be developed in this region. Finally, for those CO2 emissions that must be transported to other sites for storage, an additional premium on the energy costs associated with that transportation will affect water consumption ${ }^{49}$.

Once again, state and national policy requiring the capture and storage of carbon dioxide will be key in developing estimates of the amount of energy requirements and, consequently, the amount of water required in order to produce electricity from coal fired power plants.

\section{CONCLUSIONS - WATER SUPPLY FOR ENERGY PRODUCTION IN THE SOUTHEAST}

Adequate water supplies are an essential part of energy production in many ways, from energy resource extraction (mining) to electric-power generation. Nationally, water withdrawals for cooling and scrubbing in thermoelectric generation now exceed those for agriculture in the U.S. ${ }^{50}$ Emerging sources, such as biofuels, synfuels, and hydrogen, will add to future water demands. Another new energy-related stress on water resource systems will be the integration of hydropower with other intermittent renewables, such as wind and solar, at the power system level. Hydropower is a very flexible, low-cost generating source that can be used to balance periods when other renewables are not available (e.g., times of calm winds) and thus maintain electricity transmission reliability.

As more non-hydro renewables are added to transmission grids, calls for fluctuating hydropower operation may become more frequent and economically valuable, and may compete with other water demands. If electricity demand increases by $50 \%$ in the next 25 years, as predicted by the Energy Information Administration, then energy-related water uses can also be expected to expand greatly -an ominous trend, especially where available water resources are already over allocated.

\footnotetext{
${ }^{49}$ U.S. Department of Energy, 2007. Carbon Sequestration Atlas of the United States and Canada. Office of Fossil Energy. March.

${ }^{50}$ U.S. Department of Energy, 2006. Energy Demands on Water Resources. Report to Congress on the Interdependency of Energy and Water. Washington, DC. http://www.sandia.gov/energywater/congress_report.htm; Hutson, Susan S., Nancy L. Barber, Joan F. Kenny, Kristin S. Linsey, Deborah S. Lumia, Molly A. Maupin. 2004. Estimated Use of Water in the United States in 2000. U.S. Geological Survey Circular 1268. Reston, VA: USGS.
} 
NOAA's Climate Change Science Program has assessed the impacts of climate change on energy production and has found that the most direct effects will be through impacts on hydrologic cycle processes. ${ }^{51}$ Changes in precipitation will affect hydropower, either positively or negatively at different times and locations. Increases in storm intensity could threaten further disruptions of the type experienced in the southeast in 2005 with Hurricane Katrina. Also, average warming can be expected to increase energy needs for cooling and reduce those for warming. Concerns about climate change impacts could change perceptions and valuations of energy technology alternatives. Any or all of these types of effects could have very real meaning for energy policies, decisions, and institutions in the U.S., affecting discussions of courses of action and appropriate strategies for risk management and energy's water demands will change accordingly.

The energy-related decisions in water management are especially complex, because they usually involve both water quality and quantity aspects, and they often occur in the context of multiple-use river basins. The Tennessee Valley exemplifies these complexities. The Tennessee Valley Authority (TVA) operates an integrated power system of nuclear, coal, and hydropower projects along the full length of the Tennessee River. TVA's river operations include upstream storage reservoirs and mainstream locks and dams, most of which include hydropower facilities. Cold water is a valuable resource that is actively stored in the headwater reservoirs and routed through the river system to maximize cooling efficiencies of the downstream thermoelectric plants.

Reservoir releases are continuously optimized to produce least-cost power throughout the river basin, with decision variables of both water quantity and quality.

In 2000, approximately $52.9 \%$ of the 3.8 trillion kilowatt-hours of the total electricity produced in the United States were derived from coal. Though water plays an important role in energy production, alternative energy production methods, such as solar and wind power require little to no water for power production. Processes that withdraw less water or require less consumption should continue to be explored.

As clean coal technologies assessed for their impact on water use and ambient pollution, water pollution mitigation processes should become a research priority. CCT processes are relatively closed processes that often re-use or recycle water throughout their operation; these processes should have a significantly positive impact on the total daily pollution load of coal-fired power plant effluents. NETL and others have identified several clean coal projects as candidates for future research, and it is important to begin assessing the actual gains in water supply savings these projects have engendered.

\footnotetext{
${ }^{51}$ Climate Change Science Program. 2007. Effects of climate change on energy production and use in the United States. U.S. Department of Energy, Washington, DC. http://www.ornl.gov/sci/sap_4.5/energy impacts/team.shtml
} 


\section{Glossary}

\section{Advanced Biofuels}

Renewable fuel other than ethanol derived from corn starch that is derived instead from renewable biomass, required to achieve a 50 percent greenhouse gas emissions reduction.

\section{Aquifer}

A stratum of permeable rock that bears water. An unconfined aquifer is recharged directly by local rainfall, rivers, and lakes, and the rate of recharge will be influenced by the permeability of the overlying rocks and soils. A confined aquifer is characterized by an overlying bed that is impermeable and the local rainfall does not influence the aquifer.

\section{Basin}

The drainage area of a stream, river, or lake.

\section{Carbon Capture and Storage (CCS)}

CCS is an approach to mitigate global warming by capturing CO2 from large point sources such as fossil fuel power plants and storing it instead of releasing it into the atmosphere.

\section{Cellulosic Biofuels}

Renewable fuel derived from cellulose, hemicelluloses or lignin from renewable biomass, achieving a 60 percent greenhouse gas emission reduction requirement.

\section{Climate}

Climate in a narrow sense is usually defined as the "average weather," or more rigorously, as the statistical description in terms of the mean and variability of relevant quantities over a period of time ranging from months to thousands of years. The classical period is 3 decades, as defined by the World Meteorological Organization (WMO). These quantities are most often surface variables such as temperature, precipitation, and wind. Climate in a wider sense is the state, including a statistical description, of the climate system.

\section{Climate Change}

Climate change refers to any change in climate over time, whether due to natural variability or as a result of human activity. This usage differs from that in the United Nations Framework Convention on Climate Change (UNFCCC), which defines "climate change" as: "a change of climate which is attributed directly or indirectly to human activity that alters the composition of the global atmosphere and which is in addition to natural climate variability observed over comparable time periods." See also climate variability. 


\section{Cooling Systems:}

\section{Recirculating steam plant cooling}

Water is reused to cool steam in a closed loop system using a cooling tower or cooling pond.

\section{Once-through cooling}

Water from a lake, river or the ocean is used to condense steam and the water is returned to its source but at a higher temperature.

\section{Dry Cooling}

Air cools steam, using far less water than wet cooling technologies. Although dry cooling is not widely used, it can be effectively utilized where water supplies are limited.

\section{Desalination}

Extracting salt from seawater to make it drinkable.

\section{Drought}

The phenomenon that exists when precipitation has been significantly below normal recorded levels, causing serious hydrological imbalances that adversely affect land resource production systems.

\section{Drinking Water}

Water that is intended to be ingested by humans

\section{Ecosystem}

A distinct system of interacting living organisms, together with their physical environment. The boundaries of what could be called an ecosystem are somewhat arbitrary, depending on the focus of interest or study. Thus the extent of an ecosystem may range from very small spatial scales to, ultimately, the entire Earth.

\section{Erosion}

The process of removal and transport of soil and rock by weathering, mass wasting, and the action of streams, glaciers, waves, winds, and underground water.

\section{Evaporation}

The process by which a liquid becomes a gas.

\section{Evapotranspiration}

The combined process of evaporation from the Earth's surface and transpiration from vegetation.

\section{Extreme Weather Event}

An event that is rare within its statistical reference distribution at a particular place. Definitions of "rare" vary, but an extreme weather event would normally be as rare as or rarer than the 10th or 90th percentile. By definition, the characteristics of what is called "extreme weather" may vary from place to place. An "extreme climate event" is an 
average of a number of weather events over a certain period of time, an average which is itself extreme (e.g., rainfall over a season).

\section{Groundwater}

Water located beneath the ground surface in soil pore spaces and in the fractures of geologic formations. Typically is it thought of as liquid flowing through shallow aquifers, but technically it can also include soil moisture, permafrost, immobile water in very low permeability bedrock, and deep geothermal or oil formation water.

\section{Infrastructure}

The basic equipment, utilities, productive enterprises, installations, and services essential for the development, operation, and growth of an organization, city, or nation.

\section{Land Use}

The total of arrangements, activities, and inputs undertaken in a certain land-cover type (a set of human actions). The social and economic purposes for which land is managed (e.g., grazing, timber extraction, conservation).

\section{Prior Appropriation}

Sometimes called the "Colorado Doctrine", is a system of allocating water rights from a water source that is markedly different from Riparian Rights. Developed due to scarcity of water, it is generally used in the western United States; however the legal details vary from state to state. The general principle is that water rights are unconnected with land ownership, and can be sold or mortgaged like property. The first person to use a quantity of water from a water source for beneficial use has the right to continue to use that quantity of water for that purpose. Subsequent users can use the remaining water for their own beneficial purposes provided that they do not impinge on the rights of previous users.

\section{Reservoir}

A component of the climate system, other than the atmosphere, that has the capacity to store, accumulate, or release a substance of concern (e.g., carbon, a greenhouse gas, or precursor). Oceans, soils, and forests are examples of reservoirs of carbon. "Pool" is an equivalent term (note that the definition of pool often includes the atmosphere). The absolute quantity of substances of concern held within a reservoir at a specified time is called the "stock." The term also means an artificial or natural storage place for water, such as a lake, pond, or aquifer, from which the water may be withdrawn for such purposes as irrigation, water supply, or irrigation.

\section{Riparian Water Rights/Law}

A system of allocating water among those who possess land about its source. Under riparian principle, all landowners whose property is adjacent to a body of water have the right to make reasonable use of it. These rights cannot be sold or transferred other than with the adjoining land, and water cannot be transferred out of the watershed. It is used in the United Kingdom and the eastern United States. 


\section{Runoff}

That part of precipitation that does not evaporate. In some countries, runoff implies surface runoff only.

\section{Salinization}

The accumulation of salts in soils.

\section{Saltwater Intrusion/Encroachment}

Displacement of fresh surface water or groundwater by the advance of saltwater due to its greater density, usually in coastal and estuarine areas.

\section{Sea-Level Rise}

An increase in the mean level of the ocean. Eustatic sea-level rise is a change in global average sea level brought about by an alteration to the volume of the world ocean. Relative sea-level rise occurs where there is a net increase in the level of the ocean relative to local land movements. Climate modelers largely concentrate on estimating eustatic sea-level change. Impact researchers focus on relative sea-level change.

\section{Snowpacks}

A seasonal accumulation of slow-melting snow.

\section{Streamflow}

Water within a river channel, usually expressed in $\mathrm{m}^{3} \mathrm{sec}^{-1}$.

\section{Subsidence}

In its natural equilibrium state, the hydraulic pressure of groundwater in the pore spaces of the aquifer and the aquitard supports some of the weight of the overlying sediment. When groundwater is removed from aquifers, due to excessive pumping, pore pressures in the aquifer drop, and compression of the aquifer may occur. This compression may be partially recoverable if pressures rebound, but much of it is not. When the aquifer gets compressed it may cause land subsidence, a drop in the ground surface.

\section{Surface Runoff}

The water that travels over the soil surface to the nearest surface stream; runoff of a drainage basin that has not passed beneath the surface since precipitation.

\section{Sustainable Development}

Development that meets the needs of the present without compromising the ability of future generations to meet their own needs.

\section{Total Maximum Daily Load (TMDL)}

A TMDL is a calculation of the maximum amount of a pollutant that a body of water can receive and still meet water quality standards, and an allocation of that amount to the pollutant's sources. 


\section{Water Consumption}

Amount of extracted water irretrievably lost at a given territory during it's use (evaporation and goods production). Water consumption is equal to water withdrawal minus return flow.

\section{Water Stress}

A country is water stressed if the available freshwater supply relative to water withdrawals acts as an important constraint on development. Withdrawals exceeding 20\% of renewable water supply has been used as an indicator of water stress.

\section{Water Withdrawal}

Amount of water extracted from water bodies.

\section{Water Use Efficiency}

Carbon gain in photosynthesis per unit water lost in evapotranspiration. It can be expressed on a short-term basis as the ratio of photosynthetic carbon gain per unit transpirational water loss, or on a seasonal basis as the ratio of net primary production or agricultural yield to the amount of available water. 


\section{Bibliography- Other References}

Board of Natural Resources. Water Issues White Paper. 2001. State of Georgia. May.

Barczak, S. and C. R. Carroll. Climate Change Implications for Georgia's Water Resources and Energy Future. 2007. University of Georgia Proceedings of the 2007 Georgia Water Resources Conference. 27-29 March.

California Energy Commission. “2005 Energy Report Committee- Integrated Energy Policy Report Workshop”. 14 January.

Cane, J., ed. “Drought Highlights Vital Link Between Water, Electricity Supplies”. 2008. Nuclear Energy Insight. January.

Feldman, D. and A. Slough. Freshwater Availability and Constraints on Thermoelectric Power Generation in the Southeast U.S.: A Report to the Southern States Energy Board. 2007. University of Tennessee, Knoxville. August.

Feldman, D. and J. Elmendorf. Water Supply Challenges Facing Tennessee: Case Study Analyses and the Need for Long-Term Planning. 2000. University of Tennessee, Knoxville for Tennessee Department of Environment and Conservation, Environmental Policy Office. June.

North American Electric Reliability Council (NERC). 2008 Summer Reliability Assessment: The Reliability of the Bulk Power System. 2008. Princeton, NJ. May.

Torcellini, P., N. Long and R. Judkoff. Consumptive Water Use for U.S. Power Production. 2003. National Renewable Energy Laboratory. NREL/TP-550-33905. Golden, CO: December.

U.S. Department of the Interior/Bureau of Reclamation. Water 2025: Preventing Crises and Conflict in the West. 2005. Washington, D.C.: August. 